\title{
"Doing something in life": Rural youth reimagining technical vocational education and training
}

\section{Lucky Maluleke and Anne Harley}

(Received 6 October 2014; accepted 29 July 2016)

\begin{abstract}
Recent post-schooling policy continues to emphasise the importance of technical vocational education and training (TVET) for employability in the workplace, thus largely reflecting the interests of capital. However, the discourse of educating for employability is under increasing attack as unemployment levels rise; and recent policy has begun to argue for a consideration of skills for livelihoods other than formal employment. Unemployment disproportionately affects the youth and those living in rural areas, and TVET policy has begun to address this. However, such policy remains firmly within neoliberalism, and does not address the interests or lived experience of rural youth. A reimagining of TVET is required. In this, there is a need to understand what rural youth themselves consider to be most appropriate for local development needs. This article reports on a qualitative study done with ten youth from Limpopo Province to investigate what sort of TVET out-of-school youth consider to be relevant in their context.
\end{abstract}

\section{Introduction}

In 2013, South Africa's Department of Higher Education and Training (DHET) released the White Paper for Post-School Education and Training, which sets out "a vision for the type of post-school education and training system we aim to achieve by 2030" (DHET, 2013, p.xi). According to the White Paper, DHET's highest priority is to strengthen and expand the Further Education and Training (FET) college system (which it renames Technical and Vocational Education and Training (TVET) colleges). It also creates a new institutional type, Community Colleges, that will target those who do not qualify for, or cannot access TVET colleges. These colleges will, inter alia, "expand vocational and skills-development programmes" (DHET, 2013, p.xii). Subsequent to the release of the White Paper, this emphasis on TVET has been enacted through, inter alia, the development of a Qualifications Framework for TVET College lecturers (DHET, 2015), the publication of 
national norms and standards for funding TVET colleges, and the establishment through legislation of the South African Institute for Vocational and Continuing Education and Training. Thus vocational education and training remains an incredibly strong focus of PSET policy and implementation in South Africa.

However, according to many commentators, TVET policy in South Africa operates primarily in the interests of capital, firmly entrenched in the hegemonic discourse of neoliberalism (Akoojee and McGrath, 2003; Allais, 2011; Motala and Vally, 2014; Wedekind, 2014). In line with its nationalist agenda (Hart, 2013), government continues to argue for the need to address extreme social and economic inequalities in the country; but this is framed always within the prior need for economic growth - and hence an 'appropriate' skills base. The TVET discourse thus emphasises skills for the (formal, urban) market place. Conversely, unemployment is cast as the result of a lack of these required skills (Motala and Vally, 2014). However, as unemployment continues to rise, particularly among youth, recent TVET policy discourse has been slightly adapted to include a focus on vocational skills necessary for other livelihoods, rather than purely for formal employment; and to increasingly consider the rural, until now characterised by very low provision of TVET (Jacobs and Hart, 2012; Petersen, 2007).

Thus the White Paper recognises that post-schooling remains grossly unequal, with rural areas in particular being disadvantaged; and also emphasises the critical need to address the over three million young people who are not in employment, education or training (the so-called NEETs). In addition, beyond arguing for skills for the workplace, the White Paper proposes that "we must also find ways to assist those who find themselves outside the formal economy and in need of finding creative and sustainable ways to earn a livelihood" (DHET, 2013, p.2). Such arguments are echoed in broader policy - the National Skills Development Strategy (NSDS) III, for example, also argues that rural people must be provided with TVET which specifically speaks to rural needs (DHET, 2011). However, since local livelihoods are themselves heavily influenced by neoliberalism, including in rural areas (Petersen, 2007), simply increasing TVET provision in rural areas, and allowing for a focus on skills for livelihoods outside of formal employment, is not sufficient to ensure TVET that addresses the needs and experiences of youth living in the rural areas of South Africa. We thus argue that it is essential to ask what a truly reimagined TVET system, responsive to the lived needs of rural youth, would look like. To answer this question it is necessary 
to ask rural youth what they think - something which is generally neglected in research on TVET (Powell and McGrath, 2014).

In this article we report on a study done with out-of-school youth of Mavalani village, Limpopo Province to investigate their views on TVET policy, and what they perceive to be appropriate TVET for out-of-school youth in a rural context. The article first explores the policy framework, and its implications for rural youth, before describing the study, its findings, and implications for a reimagined TVET.

\section{TVET policy development and practice in South Africa}

Wedekind (2014) argues that South African TVET policy consistently emphasises employability and responsiveness, primarily to the needs of the labour market, whilst also, and to a lesser extent, committing to a wider development agenda. In both of these traits, it reflects neoliberal concerns.

Neoliberalism is the currently-dominant form of capitalism (Harvey, 2011), emerging out of the economic crisis of the 1970s, and "legitimised draconian policies designed to restore and consolidate capitalist class power" (Ibid., p.10). It emphasises the free market system, and argues for deregulation, privatisation and fiscal restraint, and an export-oriented national economy, and at the level of private enterprise, labour flexibility, 'just-in-time' inventory, and productivity. Overall, the system rests, theoretically at least, on high levels of competition - between nations, between companies, and between individuals (Harvey, 2011). The underlying assumption is that these mechanisms will lead to economic growth, which is essential for any social or economic development.

Neoliberalism has had a profound effect on education which is seen as building 'human capital', enhancing productivity (Allais, 2014) and employability and contributing to economic growth, rather than, for example, allowing people to achieve their human and social potential. Education under neoliberalism has seen the emergence of national qualification frameworks, a reshaped curriculum, a growing emphasis on certification, and the 'privatisation' of education in various ways. 
TVET has perhaps been the most affected (Akoojee and McGrath, 2003; Allais, 2011; Motala and Vally, 2014; Wedekind, 2014) and policy is "closely tied to economic goals through the production of individuals with the knowledge, skills and dispositions necessary to enhance their own and national competitiveness within the global economy" (Kgobe and Baatjes, 2014, p.2). One of the latest moves in TVET policy development, the FET Colleges Amendment Act, argues that Colleges must be more responsive to the needs of the economy so that graduates are more employable (Wedekind, 2014).

However, whilst neoliberalism argues that increasing education leads to greater employability, it inherently rests on sustained levels of unemployment since capitalism requires a reserve army of labour (Harvey, 2011; Motala, 2014). Unemployment creates social and economic exclusion (Motala and Baatjes, 2014), and growing inequality, precisely as a result of (always uneven) economic growth (Motala, 2014). Unemployment disproportionately affects youth, leading to the rise of those now routinely referred to as the NEETs (not in employment, education or training). The NEETs are a possible source of social and political instability (acknowledged in the White Paper on PSET; and, as Wedekind (2014) argues, much government policy focuses on issues of inequality and 'development'). The neoliberal response is two-fold. Firstly, it argues that unemployment results from a lack of the skills necessary for employment. Education is responsible for supplying the labour market with skilled workers, and individuals are responsible for making themselves employable (Klees, 2014). In fact, this is a fallacy - as Treat and Motala (2014) and Motala and Vally (2014) show, unemployment is not a worker supply problem, it is a structural function of capitalism. Secondly, the notion of individual competition and individual responsibility is used to argue that people need to create their own jobs through 'entrepreneurship' located firmly within capitalism - small (or medium or micro) businesses generating profit. The 'livelihoods' which have recently emerged in policy discourse are securely framed within this terrain.

Thus, whilst inequality, poverty and unemployment have been constant refrains in government policy documents (Motala and Vally, 2014; Wedekind, 2014)), the mechanisms to alleviate these, including TVET, remain fundamentally within the neoliberal frame. Thus, "the drive for international competitiveness has won out over equity" (Petersen, 2007, p.455). This is reflected in rural development policy. 


\section{Rural provision of TVET in South Africa}

Since 1994, there have been a number of state initiatives targeting rural areas, including the Integrated Sustainable Rural Development Programme (ISRDP) (2003), the Agricultural Education Training Strategy (AETS) (early 2000s), the Comprehensive Rural Development Programme (CRDP) (2009), and the National Rural Youth Service Corps (NARYSEC) (2010). Many of the earlier initiatives included little or no training, or training which failed to take into account the specific needs of rural people. Both the ISDRP and CRDP have been critiqued for providing "welfarist" (Jacobs and Hart, 2012, p.3) service delivery, for example free houses, without extending the skills of rural people to participate in this kind of development. An evaluation of the Department of Agriculture's AETS, specifically intended to train citizens in ecologically and economically viable agriculture (DoA, 2005), found that it failed to speak directly to rural TVET needs, and that disadvantaged people had limited access (Department of Agriculture, Forestry and Fisheries, n.d., p.2).

Within the last five years, government has argued for prioritising rural development and the provision of skills for rural development (DHET, 2011), and this, together with the critiques of the initiatives discussed above, has sparked increased awareness of the need for specifically-targeted training in rural areas. The National Development Plan (NDP) argues that an integrated and inclusive rural economy is needed, and that the creation of economic activities, agricultural and non-agricultural, will require the development of capabilities, knowledge and skills, whether vocational or non-vocational (National Planning Commission (NPC), 2011). The NSDS III (2010-2015) thus makes clear that education and training efforts are often not sufficiently directed to rural needs, and that this needs to be corrected:

However, we must make a distinction between training of rural people and skills for rural development. The former has tended to train rural people only in order to migrate to the urban areas, whilst the latter will aim to train rural people for development of the rural areas themselves (DHET, 2011, p.7).

From 2010 NARYSEC thus specifically offered a two-year VET programme for rural youth to equip them with vocational skills like construction (Department of Rural Development and Land Reform, 2011), so that youth could build houses and roads in their respective rural communities (Gabara, 2010). According to Jacobs and Hart (2012), by 2012 NARYSEC had made a huge difference in training and skills development for rural youth because it 
allowed young people to further their skills, find jobs in the formal sector, and also create their own livelihoods. However, issues of the sustainability of the programme became increasingly evident, and with budget cuts, a critical review was undertaken (Van Staden, 2015) and, since March 2015 trainees must have at least a Grade 12 (rather than Grade 10), be between the ages of 18 and 25 (rather than 35), and live in an area where there are existing projects or institutions, such as agriparks. Formal training is conducted centrally at Thaba Nchu TVET College, and is increasingly tied to formal businesses in terms of workplace experience. In this regard, potential programmes for workplace experience are chosen in terms of provincial development priorities, the skills needed, and the appropriateness of these for rural development. It is thus arguable that NARYSEC has become increasingly tied into the formal, urban economy.

However, we still have relatively little knowledge about rural skills development as most research focuses on sectoral or occupational skills, and provision is limited (Jacobs and Hart, 2012). In addition, many approaches to rural skills development focus on agriculture and other primary sector activities (Perret, 2004), ignoring the fact that rural development (and livelihood) is flexible and complicated, involving various pathways (Jacobs and Hart, 2012). This trend continues in much South African policy, including the NPC (2011), which has stated that by 2030 rural communities should be in a position to participate in the socio-economic and political matters of the country; and therefore rural people need to be trained in agricultural skills.

\section{Provision of TVET to youth}

Despite progressive government statements about nurturing youth in national development, youth remain marginalised, including from the South African and global labour market (Bhorat, 2010; DHET, 2012; DPLG, n.d.; Lam, Leibbrandt and Mlatsheni, 2008; NPC, 2011), and long-term unemployment disproportionately affects young people. By 2013 about two-thirds of all unemployed people in South Africa were below the age of 35, with the unofficial unemployment rate for this group standing at 50\% (the official rate is 36\%). Youth unemployment has been referred to as 'South Africa's ticking time bomb' (Hayes, 2014). Many of these young people left school early, and officially $47 \%$ of those who do not hold a matric certificate are unemployed; the chances of getting a job with a matric certificate is only $30 \%$ (Hayes, 2014). The number of NEETs between the ages of 15 and 24 in South Africa 
is now estimated to be 3.5 million (Wedekind, 2014). Unsurprisingly, recent TVET policy takes serious note of the challenge of NEETs (DHET, 2012, 2013). The White Paper, for example, creates a new institution, the Community College, to cater for adults and youth who did not, for various reasons, complete their schooling, or who do not qualify to study at TVET colleges or universities. These colleges are intended to be far more accessible to local communities (DHET, 2013).

With its references to skills for livelihoods, potentially locally-accessible Community Colleges, and providing opportunities specific to rural areas and youth (DHET, 2013), emerging policy could be seen as offering new possibilities. However, as argued above, such policy is developed by, and serves the interests of, the most powerful in society - for example, when rural education policies are made, rural people are generally not consulted, and their experiences are neither fully understood nor appreciated by policy makers (Nelson Mandela Foundation (NMF), 2005).

In the following section, we briefly describe the study which elicited data from rural youth on their views about appropriate rural TVET.

\section{The study}

Much research and evaluation on the TVET sector has "displayed a methodological deafness to the voices of learners, lecturers and communities" (Powell and McGrath, 2014, p.7), making sweeping assumptions about what such silenced voices value from TVET. It is thus imperative to consult those whom the system is supposedly designed to serve. The aim of the study presented in this article was to investigate what sort of TVET out-of-school rural youth consider to be relevant in their context.

The study thus focused on the views of out-of-school rural youth in Mavalani Village, Limpopo Province, and was deliberately situated within the critical paradigm. Unlike the interpretive paradigm, which seeks to understand the views of participants, and how they make sense of a particular phenomenon, critical research is concerned with issues of power, both in relation to the phenomenon being studied, and in relation to the research itself. For critical research, other research paradigms are seen as complicit in unequal power 
relations. Mies (1983, cited in Kirby and McKenna, 1989), for example, argues that research is largely an instrument of dominance and the legitimation of power elites; and Kirby and McKenna argue that for many 'on the margins', research and knowledge simply don't reflect their lived experiences. Rather, research was about "engineering. . .consent" (p.23). They (and others) thus argue for a kind of research that begins:

to reflect the experience and concerns of people who have traditionally been marginalized by the research process and by what gets counted as knowledge (Kirby and McKenna, 1989, p.22).

In our study, data were collected through a qualitative, participatory approach by the lead author who was born and raised in Mavalani Village. As a peer of many of the research participants, relations between the researcher and the research participants were considerably (though of course not entirely) equalised. Data was inductively coded, and the codes were then categorised to identify dominant and non-dominant themes (Welman, Kruger and Mitchell, 2005). This process ensured that the actual words and ideas of participants are discussed (Cohen, Manion and Morrison, 2007). A critical lens was adopted in making sense of the themes. The research also consciously positioned itself within a critique of the current phase of capitalism, neoliberalism, and the ways in which this system entrenches ruling class power.

\section{Mavalani village}

Mavalani is a deep rural village of just over 1200 Black African households (Mopani District Municipality, n.d.) about $15 \mathrm{~km}$ from the town of Giyani in the far north-east of Limpopo Province. It covers an area of $4.96 \mathrm{~km}^{2}$ (Mopani District Municipality, n.d.; Statistics South Africa, 2012). It falls under the Greater Giyani Municipality, in the Mopani District. Giyani town provides the only major employment opportunities, both formal and informal, and the primary shopping and recreational facilities (Greater Giyani Municipality, 2010). The 2011 census shows that the province has not experienced high population growth since 1996, while Mopani District as a whole experienced a decline (Lehohla, 2012; Statistics South Africa, 2012).

Although agriculture is an important economic activity in Greater Giyani, various structural and environmental constraints mean that Mavalani village residents hardly grow their own food and most of the products that people need are purchased from stores in Giyani (Greater Giyani Municipality, 2010). 
Except for local schools and churches used as adult learning centres, there is no education and training centre within the village. Youth have to leave the area to further their studies or receive training. In Giyani there are colleges, such as Letaba FET College (public), Mass Computer Training (private) and Avuxeni Computer Academy (private), that offer programmes in computer literacy, motor mechanics, electrical engineering, and office administration, amongst others. A community needs assessment for Mavalani village conducted in 2011 found that the majority of youth of Mavalani village are unemployed, and are barely trained or educated (Milliner, 2011).

\section{Data collection and analysis}

The participants were 10 out-of-school youth (five men and five women) between the ages of 18 and 30 who live permanently in Mavalani Village, and grew up and went to school there. In 2012, when the study was conducted, none were working or studying. The highest level of education that the participants held is Grade 12, with two of the ten not having achieved this. Data was gathered from the group using Community Mapping; Community Timeline; Political, Economic, Social and Technological (PEST) Analysis; and Focus Group Discussion (FGD). The participatory tools were used as the basis for the discussion in the FGD. Community mapping allows participants to produce a visual representation of the village, community or place under investigation in order to create a common knowledge base among the participants (Melcher, Keith, MacDowell, Foster-Fishman, Buurma, and Rozdilsky et al., 1998-1999). A community map also shows the structure of the community and the resources available, as well as their location and availability (Harley and Butler, 2009). A 'timeline' is a participatory tool or technique used to show the history of remembered events with approximate dates and how things have changed within a particular community or village (Chambers, 1994). It helps participants see connections between events, and make future decisions. The timeline was used to locate the community in history; to identify education and training interventions that took place in the past; problems that required education and training; and interventions that succeeded and those that did not. This helped the participants discuss the type of TVET that they thought would be appropriate and relevant to their rural context. In the Political, Economic, Social and Technological (PEST) analysis, each of these aspects are broken down and considered at local, national and global level, so that their impact on other aspects of society is not 
overlooked (Bensoussan and Fleisher, 2008). Freire (1970) asserts that learners need to be able to read the world, not only the word; and PEST is useful for this. These participatory methods allowed for maximum participation by the youth, and meant that the process was driven by their own understanding and analysis of their lived experience.

Most of the data related to the kind of TVET system they believed would better serve their interests was gathered during the FGD. The deep discussion enabled reflection from participants and the collection of in-depth information. The FGD was conducted in Xitsonga, the mother tongue of all of the participants, to allow them to express themselves fully without a language barrier. The entire data collection process was recorded, transcribed, translated and then thematically analysed.

At the time of the research, the White Paper on Post School Education and Training had not yet been published, only the prior Green Paper. No participants were aware of the Green Paper, but all had some ideas and understanding about TVET training colleges. Current and proposed government policy, up to that date, particularly regarding TVET, was accordingly presented to the group. ${ }^{1}$

\section{Findings}

The participatory methods allowed participants to begin from their own, lived experience. The participants identified many context-related problems faced by the youth of Mavalani Village, including those of poverty, unemployment, and education, which they understood to be interlinked. On the whole, the youth were very critical of the existing education system, both at schooling and post-school levels. Criticisms of school focused on the quality of education offered in rural areas:

Although some of the terminology used in the White Paper is different from that in the Green Paper, the key concepts remain the same. Thus whilst the research explored responses to the CETCs proposed in the Green Paper/task team report, these are clearly applicable to the Community Colleges proposed in the White Paper. 
When we look at rural schools, it seems as if the education there is very poor. You find that a matric student passes matric without the ability to use the English language, whether it is to read or write. They experience serious problems when they get to institutions of higher learning. But kids from urban areas are far better than those from rural areas (Mujaji).

Many of the participants spoke about barriers to schooling and post-schooling education, such as the cost of uniforms or transport, high rates of teenage pregnancy (a very significant problem in the area, which made national headlines in early 2014), and alcohol abuse; but also, significantly, the lack of incentive to attend and complete high school, because of high post-schooling unemployment rates:

Another thing is that some people are weak. Their weakness is that when they see older youth who have been to institutions of higher learning staying at home without employment, they use it to explain why they do not need to go to school. They would say 'so and so went to university but he is not working, so what difference does it make? Why should I even bother going to school? '(Mujaji).

Many of the youth also spoke about a lack of guidance about future possibilities, and lack of support and resources:

The time we were still at school we did not know a lot of things in terms of education and many other things, or knowledge that would help us make right decisions. You would find that when you wanted to follow a certain career in a certain university or technikon, or wherever, you would find that you knew very little about such a career. In class there is nothing you learn about careers, and at home it is worse; there is no one to guide you. You see, so according to my views, to be in a situation where there is no one to guide us is one of the main problems that we are facing. On top of that, as we said...poverty. Sometimes some people have a desire to do something good in life, but you find that their financial situation does not allow them to move forward. Some people do wish to go to school, sometimes they receive relevant information about financial assistance, but they cannot afford travelling costs, and you find that they have many other problems. So you find that poverty can be a major problem in our lives as youth (Muyisa). 
Participants were largely critical of current post-schooling TVET, particularly in the case of FET (TVET) Colleges. Firstly, they were very critical of the kind of TVET provided by these Colleges:

Yes, FETs have been built, there are FETs all over. But let us look at the education that people receive at FET colleges. . They have built FET colleges, but they did not put in place programmes that will help people with necessary skills, the skills that are needed by the citizens who are living at this time we are living in (Yila).

However, they also argued that there were simply too few colleges to allow sufficient access:

Although we have a small number of FET colleges. . if people pass Grade 12. . if indeed the government would put more value on vocational training, and improve the programmes that exist in the existing colleges, would they be big enough to accommodate all people who need access? Would all people be accommodated? Do we have enough colleges? In other words I can say the government has not made enough effort to make sure that people receive education and training, especially vocational training (Yila).

As mentioned previously, no participants were aware of the Green Paper, although all had some idea of what is going on in the education and training system in South Africa. They were also largely critical of emerging TVET policy, which they did not see as offering anything new. In fact, youth tended to be fairly negative about government in general:

The government is failing to reach out to the people who want to further their education and training. Even though people initiate their own projects, it takes a long time for the government to fund such initiatives. In fact the government is useless to young people (Mujaji).

The youth had many ideas for a reimagined TVET. In many respects their vision contrasts sharply with that proposed in current government policy. They argued for a broader conception of TVET than that offered by the Colleges, one that includes not only skills for possible employment in urban areas, but also locally useful, livelihoods-related skills, including agriculture, but also construction, bricklaying, plumbing, motor mechanics, carpentry, sewing, and skills required in beauty salons. They saw these skills as 
continuously in demand, because they are skills necessary for daily lives. They emphasised the need for both up-to-date technological know-how and locally appropriate technologies:

The process of building is unending...Even if we can build everywhere and leave no space for new buildings, some people will want to change something, or renovate. The water pipes that have been installed do erupt some times, and they need to be fixed. We, in the rural areas do not even have a sanitary system. There is no sewage system here at Mavalani. Maybe we can build it. . . If now we wanted to create a sewage system, we call someone from Japan to do it for us here at Mavalani. But if we can have young people who have learned the skills to sit together, and plan, they can create a sewage system for us. If you can combine plumbing and drawing, drawing is engineering. . . you can do a lot (Yila).

The youth clearly saw these kinds of skills as part of building a local economy:

Products can be produced here, and we can buy them from here. If we buy from other places our money goes away. But if we buy locally, the money circulates in our community. For example, there is a place at Shayandima in Venda where people produce wardrobes. Some of these people are people with disabilities. So people from Shayandima do not go out to buy wardrobes and the wardrobes that they buy locally are cheaper (Mujaji).

This is not to suggest that participants did not talk about skills related directly to the market. Indeed, many of the participants saw skills as being as much about the broader marketplace as local livelihoods, and argued that TVET needed to include skills related to manufacturing and marketing. So discussions about farming, carpentry and sewing were also related to these broader issues and skills:

The issue of farming takes the front seat, not that other things are not important, but farming is basic. It is not bad for us to make tomato sauce. What is wrong if tomato sauce is sold here at Mavalani? What is wrong if we make tomato sauce that is sold in the whole country from our village farm? It is not wrong. Or there is a firm that 
manufactures baked beans, and the beans are grown in a local farm. What is wrong with that? There is nothing wrong with that. These are the things we must understand, and the process of doing it. We must compile a list of all we need, and it is what must be taught and learned. And the issue of. . . in the secondary sector, we need skills to make things, we must manufacture things. Carpentry is a secondary sector activity, it is manufacturing (Yila).

However, significant emphasis was placed on making things by hand, rather than by machine:

I think carpentry can be very important in our village, in terms of developing people. . . and as a way to bring something good to our community. Like for example, back in the day I was lucky to see my grandfather doing carpentry. In fact there are beautiful things to adorn the house and they come in different shapes. These days when you look at the headboards, you can see that the art that is used there is not of a machine, but of someone's hands who gave himself time to craft, to carve, using different kinds of tools (Muyisa).

Something that is made by hands is more attractive than something made by a machine. If there can be people who would do carpentry, they can be able to produce sellable goods. For example, when a radio is playing, no one pays attention, but if one plays the traditional drums, people pay attention and they dance to it. So when it comes to carpentry, people prefer products made by hand, as opposed to those made by machine, because the ones made by hand are more beautiful. As a result of carpentry we can manage to sell things that are made by us (Munhu).

What is also profoundly different about the youth's reconceptualisation of TVET was the considerable emphasis placed on inclusiveness - both in terms of different cognitive abilities and also physical abilities:

The government encourages people to do Science and Mathematics. But you find that there are young people who cannot do those subjects. But. . .with their hands, they can do a lot. So if there is something like carpentry, there will be some form of equality because everyone will do what they like, and they will find themselves doing something in life. Those who fail to go to university, those who fail to 
do subjects that are promoted by society, they can resort to something like carpentry if it is their thing, and they will earn a living (Khubani).

Vocational skills like carpentry are good in a community like this one. . some people are deaf and there is no provision for such people locally. . . A deaf person cannot learn with people who are not deaf, and since there is no provision for deaf people, there must be alternatives. To do carpentry you do not need ears, just your hands and eyes, so deaf people can do it as well (Rito).

Here TVET is not simply a mechanism to build individual 'human capital', but a potentially communal, collective endeavour. Participants argued that TVET could and should contribute to the general well-being of the village; build social relations; improve communication between people; and develop a broader and deeper understanding of the world:

The importance of education is to ensure that when we meet with other people, we are able to relate to them, for example through language and social understanding. Education helps us communicate well with other people (Rito).

The importance of education varies from one person to the next. Some people need education just to secure employment, and it is ok to them. . better job. . . better job. But the importance of education also includes learning the behaviour, how you conduct yourself. But some people want to get jobs, nothing more, and they do not care about self-conduct. But the importance of education is to teach you how to treat other people well, and to get a job perhaps (Mujaji).

[E]ducation teaches you how to speak with other people in a good way. You do learn that you do not just say anything randomly; you learn a constructive way of communicating with other people (Khubani).

Thus, in their discussion, producing local goods was also frequently tied to preserving and promoting local culture. So, for example, making clothing locally would not simply save money, but also build local culture. 
As discussed, participants felt that TVET in South Africa is of very poor quality, does not speak to local needs, and that government has done very little to improve it. Since TVET colleges remain the most important providers of TVET, the participants argued that TVET in these colleges needs to be improved, and needs to allow for education that is more than simply 'to secure employment' (Khubani).

In relation to the proposed community learning centres (CLCs - connected to Community Colleges), the youth emphasised that these must be accessible to all:

First and foremost it must be in a place where most people can access it, and it must be designed to accommodate everyone. I think that anyone who wants to learn certain skills or skills that will be offered is welcome to attend (Yila).

It must be accessible to anyone who is interested in attaining some education and training (Munhu).

Participants discussed the nuts and bolts of provision at the CLCs extensively, covering aspects such as payment, accreditation and certification, and educator training. While one participant believed that "It must be free because some of us do not have money...[people] may end up stealing money in order to pay because there is no money at home" (Rito), the other participants argued that when people pay, they place value on the education and training that they receive, and take it seriously.

For people to place value in the CLC, not that we want to make things difficult, there must be a certain amount that a person pays. It can be in form of a study loan which people can pay when they start working or when they have started to make production. We do this so that people can place value in their education that they will obtain from the centre (Yila).

Participants strongly believed that qualifications should be accredited and certificated: "Some people cannot speak for themselves, so the certificates will speak for them. The certificates will indicate what the person has learned, and their abilities" (Munhu). Some argued that without certificates, any person can claim that they graduated from the local CLC even if they cannot 
perform a task, and that will bring the local CLC into disrepute. Moreover, certificates help control the education and training system as a whole:

It is like when people pass Grade 12, they receive statements of results. If there were no statements of results, we would all move from Grade 12 straight to universities and start attending. The universities would be overcrowded to an extent that lecturers would fail to teach. Since there are papers, they are able to control the number of people who go in, and people will always know that to gain access they must work for it. People will always know that they have to work hard to get a certificate in order to gain future access in various areas. So if there are no papers it would be chaos everywhere; there will be no system of control (Rito).

Thus certificates help motivate people to study:

Those who decide not to attend the CLC will see the certificates of those who attend, and they will see that they are progressing, so they will be motivated to attend too. But if there are no papers, people will just laugh and say: 'how do we see that you are learning? Where are the papers to prove that you are learning?'(Muyisa).

Two participants argued that accreditation and certification promote professionalism and 'seriousness': "Certification and accreditation will help with professionalism. . . Professionalism means that people will not take our CLC for granted, thinking that it is a game" (Yila).

In terms of educators at CLCs, participants argued that local people should be employed as educators at the CLCs, and clearly valued the skills that local people possess:

I would say that since there are too many of us in the village, if we look for external people to teach, it will not benefit local people but outsiders. Since we know what specific individuals can do, for example we know who does some form of carpentry, so we can appoint that person to teach. We know that grandfather Goda is a good bricklayer, so we can appoint him to teach people how to build. What will actually happen is that people will be happy to be taught by 
grandfather Goda to build because he is good, they will want to build like him (Tivani).

\section{Discussion and conclusion}

In many ways, the Mavalani context is fairly typical to that of other rural youth around the country, facing very similar problems and issues (see, for example, Bhana, Clowes, Morrell, and Shefer, 2008; Gardiner, 2008; NMF, 2005; Macleod and Tracey, 2010; Pretorius, 2007). So, while the results of this small qualitative study are not necessarily generalisable, the participants' perceptions are useful in reimagining how TVET might be made more appropriate to local, rural contexts; specifically, that TVET should be not only provide skills for employment, in urban areas, but rather should be locallyuseful and livelihoods-related. Such TVET should include a broader understanding of education that contributes to general well-being and improved social relations, rather than focusing on the individual; it should thus be inclusive in nature, and link to local culture.

Some key provisions of the White Paper clearly 'fit' the concerns of the participants. Improving TVET colleges is welcomed by the participants, as is the suggestion of local Community Colleges. The creation of Community Colleges could address issues of accessibility, both in terms of geographic locality and in terms of providing an alternative access route for those who do not qualify for TVET colleges because of poor quality local schooling. Community Colleges also potentially allow a second chance to those who did not complete their schooling because of teenage pregnancy (although childcare might need to be provided), poverty (although costs would need to be kept low, or financial assistance provided), or a lack of incentive (although, clearly, they would need to find an incentive for a second chance).

In their discussion on how new and improved TVET and Community Colleges might function, their emphasis on accreditation and certification is telling. Their discussion reflects the ways in which the labour market 'judges' their 'employability' - it is clearly not sufficient for people to undergo education and/or training, whether formal, non-formal or informal, and demonstrate the skills, knowledge and attitudes learned, since employers will not accept this as 'proof'. However, the youth are clearly very aware that many ways of learning outside of the formal - by watching others, by simply 
doing - are powerful and useful, as is evidenced by their arguments about who should be allowed to teach in TVET and Community Colleges.

What is clearly critical is the kind of TVET offered, whether by TVET or Community Colleges. Those critical of the neoliberal influence argue for a different conception of TVET, emphasising its importance in broader social development (Motala and Vally, 2014; Powell, 2014; Wedekind, 2014). This requires that we rethink education in relation to the kind of society we want, potentially outside the capitalist frame, and draw on notions such as capabilities (Powell and McGrath, 2014), or socially useful work (Motala, 2014) in exploring what a new TVET might look like:

Education and training must relate not only to the diminished possibilities of formal employment but also to socially useful jobs outside of the formal labour market (Motala and Baatjes, 2014).

We also think that the notion of "really useful knowledge", as opposed to "merely useful knowledge" (which simply serves to retain the status quo, and keep people in their place) is worthy of further exploration in this regard. "Really useful knowledge" emerged in the early $19^{\text {th }}$ Century from the worker self-education movement in parts of Europe; and has been explored in relation to vocational education by, amongst others, Kilminster (1997) and Fischer and Ziebell (2005). However, there has been relatively little work done in this area, and we would propose this as a fruitful area for further research.

This study sought to investigate what kind of TVET the participants find appropriate for local development needs, as opposed to what labour markets and governments think. It is clear that rural youth are perfectly capable of both analysing emerging policy, and proposing alternative models which better reflect their lived reality and interests. In this, they are suggesting a reconsideration of the very purpose of TVET in the current context.

We would argue that what the youth have to say is an important part of the process of not simply reimagining TVET, but reimagining it in relation to a new kind of society. Participants emphasised the need for TVET relevant to their local context that provided them with both vocational skills and broader education. They wanted skills for the market place, but also for livelihoods, to develop and secure local culture, to improve inter-personal communication, to help them understand the local and wider context. According to the 
participants, education is about communication, social interaction and intellectual development. We need to learn in order to understand our position in society as a whole, and how we fit in, as well as how we can make contributions and changes in the already existing structures, and most importantly, how we can create our own systems:

You must understand how you live as a human being, and how the person next to you lives. . For example you must know that when food is produced, how the systems that are set up in the world operate. It enables you to understand how things work, and how you as a person fit in, and understand how you need to survive as an individual and how your brother/sister next to you survives. That is what I know the importance of education to be. . Education must give you the foundation to understand how the world systems work, or to create new systems of your own if necessary (Yila).

\section{References}

Akoojee, S. \& McGrath, S. (2003). Globalization and education and training in South Africa: On being Gear(ed)! Paper prepared for the RUIG Research Programme. Pretoria: Human Sciences Research Council.

Allais, S. (2011). Will skills save us? Rethinking the relationships between labor markets, social policy, and skills development. International Journal of Educational Development, 32(5), 632-642.

Allais, S. (2014). Skills? What skills? Jobs? What jobs? Post-School Education Journal, 1(1), 13-14.

Bensoussan, B.E. \& Fleisher, C.S. (2008). Analysis without paralysis: 10 tools to make better strategic decisions. New Jersey: Pearson Education.

Bhana, D., Clowes, L., Morrell, R., \& Shefer, T. (2008). Pregnant girls and young parents in South African schools. Agenda, 22(76), 78-89.

Bhorat, H. (2010). Unemployment in South Africa: Descriptors and determinants. Presentation to the Commission on Growth and Development, World Bank, Washington, DC. 
Chambers, R. (1994). The origins and practice of participatory rural appraisal. World Development, 22(7), 953-969.

Cohen, L., Manion, L., \& Morrison, K. (2007). Research methods in education. 6th edition. London: Sage.

Department of Agriculture. (2005). National education and training strategy for agriculture and rural development in South Africa. Pretoria: Department of Agriculture.

Department of Agriculture, Forestry and Fisheries. n.d. Agricultural Education and Training Access Barriers Report. $<$ http://www.nda.agric.za/doaDev> 11 March 2012

Department of Higher Education and Training. (2011). National skills development strategy III. Pretoria: Department of Higher Education and Training.

Department of Higher Education and Training. (2012). Green paper for postschool education and training. Pretoria: Department of Higher Education and Training.

Department of Higher Education and Training. (2013). White Paper for postschool education and training. Pretoria: Department of Higher Education and Training.

Department of Higher Education and Training. (2015). Policy on minimum requirements for programmes leading to qualifications for educators and lecturers in adult and community education and training. Pretoria: Department of Higher Education and Training.

Department of Rural Development and Land Reform. (2011). National rural youth service corps.

$<$ RLINK"http://www.info.gov.za/"\hhttp://www.info.gov.za> $>11$ October 2012.

DPLG. n.d. Report on the baseline research for youth development, gender equity and disability. <www.cogta.gov.za $>1$ May 2012. 
Fischer, M.C.B. \& Ziebell, C. (2005). Really useful knowledge. Adults Learning, 16(10), 20-21.

Freire, P. (1970). Pedagogy of the oppressed. New York: Continuum.

Gabara, N. (2010). Programme to create 10000 jobs for rural youth. South African Government News Agency. <http://www.sanews.gov.za/southafrica/programme-create-10-000-jobs-rural-youth> 21 March 2012.

Gardiner, M. (2008). Education in rural areas. Issues in Education Policy, No. 4. Johannesburg: Centre for Education Policy Development.

Greater Giyani Municipality. (2010). Greater Giyani Municipality adopted integrated development plan 2010-2013. <www.limpopo-dlgh.gov.za > 6 May 2012

Harley, A. \& Butler, M. (2009). Research for a change: A community handbook on participatory action research. Pietermaritzburg: CINDI.

Hart, G. (2013). Rethinking the South African crisis: Nationalism, populism, hegemony. Pietermaritzburg: UKZN Press.

Harvey, D. (2011). The enigma of capital and the crises of capitalism. London: Profile.

Hayes, S. (2014). South Africa's ticking time bomb. U.S. News World Report 2 July. $<$ http://www.usnews.com/opinion/blogs/worldreport/2014/07/02/south-africas-major-problems-youth-unemploymentand-economic-inequality $>29$ February 2016

Jacobs, P., \& Hart, T. (2012). Skills development in rural areas: A brief review of evidence. RIAT Concept Paper, No 1. Pretoria: HSRC-EPD.

Kgobe, P., \& Baatjes, I. (2014). White Paper on post school education and training: Some new policy directions. Post-School Education Journal, $1(1), 2-4$.

Kilminster, S. (1997). Vocational education and really useful knowledge. $27^{\text {th }}$ Annual SCUTREA conference proceedings: Crossing borders, breaking boundaries: Research in the education of adults.

Kirby, S. \& McKenna, K. (1989). Experience, research, social change: Methods from the margins. Toronto: Garamond. 
Klees, S.J. (2014). Foreword. In S. Vally \& E. Motala, (Eds), Education, the economy and society (vii-ix). Pretoria: UNISA Press.

Lam, D., Leibbrandt, M., \& Mlatsheni, C. (2008). Education and youth unemployment in South Africa. Southern Africa Labour and Development Research Unit Working Paper, No. 22. Cape Town: SALDRU/University of Cape Town.

Lehohla, P. (2012). Census 2011 Municipal Report: Limpopo (Report No. 03-01-57). Pretoria: Statistics South Africa.

Macleod, C.I. \& Tracey, T. (2010). A decade later: Follow-up review of South African research on the consequences of and contributory factors in teen-aged pregnancy. South African Journal of Psychology, 40(1), $18-31$.

Melcher, J., Keith, J.G., MacDowell, M., Foster-Fishman, P., Buurma, M., \& Rozdilsky, J.L. (1998-1999). The several forms of "Community Mapping" - 2. Best Practice Briefs, 4: pp.1-2.

Milliner, V. (2011). Community needs assessment: Mavalani village. Unpublished Research Report for Community HIV/AIDS Outreach Project 2011-2013.

Mopani District Municipality (n.d.). Identified Projects - Greater Letaba: Ward 1 - Greater Giyani: Ward 20 and 23. Limpopo Province, Republic of South Africa.

Motala, E. (2014). On the White Paper. Post-School Education Journal, 1(1), $5-6$.

Motala, E., \& Baatjes, I. (2014). NMI and CIPSET's approach to education, the economy and society. Post-School Education Journal, 1(1), 9.

Motala, E., \& Vally, S. (2014). "No one to blame but themselves": Rethinking the relationship between education, skills and employment. In S.Vally, \& E. Motala (Eds). Education, the economy and society, (1-25) Pretoria: UNISA Press. 
National Planning Commission (NPC). (2011). National development plan: Vision for 2030. Pretoria: The Presidency.

Nelson Mandela Foundation (NMF). (2005). Emerging voices: A report on education in South African rural communities. Cape Town: HSRC Press.

Perret, S. (2004). Matching policies on rural development and local governance in South Africa: Recent history, principles, and current challenges. Post Graduate School for Agricultural and Rural Development, University of Pretoria.

Petersen, C. (2007). Education and training out of poverty? Adult provision and the informal sector in fishing communities, South Africa. International Journal of Educational Development, 27, 446-457.

Powell, L. (2014). Capability or employability? Rethinking the role of VET within a capabilities framework. NORRAG NEWS, 46, 26-29.

Powell, L., \& McGrath, S. (2014). Exploring the value of the capability approach for vocational education and training: Reflections from South Africa. In G. Carbonnier, M. Carton, \& K. King, (Eds), Education, learning, training: Critical issues for development (126-148). Boston, MA: Brill-Nijhoff.

Pretorius, S.G. (2007). South Africa. In C.C.Wolhuter, E.M. Lemmer, \& N.C. de Wet (Eds), Comparative education: Education systems and contemporary issues (26-46). Pretoria: Van Schaik.

Statistics South Africa (2012). Statistical release (Revised): Census 2011. Pretoria, Statistics South Africa.

Treat, J., \& Motala, E. (2014). Misrepresenting the causes of unemployment. SACSIS, 15 April. Retrieved from $<\underline{\text { http://sacsis.org.za/site/article/1976 }>}$ 1 March 2016.

Van Staden, A. (2015). National Rural Youth Service Corps (NARYSEC). Presentation to DHET Task Team meeting, Johannesburg, 20 October. 
Wedekind, V. (2014). Further Education and Training Colleges:

Employability, responsiveness, and the role of education. In S. Vally, \&

E. Motala (Eds.), Education, the economy and society (57-80). Pretoria: UNISA Press.

Welman, C., Kruger, F., \& Mitchell, B. (2005). Research methodology. Cape Town: Oxford University Press.

Lucky Maluleke

School for Education Research and Engagement

Faculty of Education

Nelson Mandela Metropolitan University

Lucky.Maluleke@nmmu.ac.za

Anne Harley

School of Education

University of KwaZulu-Natal

harleya@ukzn.ac.za 
110

Journal of Education, No. 66, 2016 